These criticisms, however, are about points of detail. The overall concept of the work is good and the author has contributed considerable time, effort and scholarship to it. $\mathrm{H}_{\Theta}$ is to be congratulated on his firmness of purpose and on successfully presenting an Introduction of such wide scope.

W. Galbraith

\section{INTRODUCING ELECTRONICS}

\section{An Introduction to Electronics}

By Dr. Dennis F. Shaw. Pp. vi+338. (London: Longmans, Green and Co., Ltd., 1962.) 30s. net.

\section{Electronics for Scientists}

Principles and Experiments for Those Who use Instruments. By Prof. H. V. Malmstadt, Prof. C. G. Enke and Dr. E. C. Toren, jun. Pp. xi+619. (New York: W. A. Benjamin, Inc., 1962.) 10.75 dollars.

\section{Physical Electronics}

By Prof. Curtis L. Hemenway, Prof. Richard W. Henry and Martin Caulton. Pp. xiv + 396. (New York and London: John Wiley and Sons, Ltd., 1962.) $62 s$.

WHETHER a sixth-form physics teacher ought to review a university-level book is a point that the writers of blurbs and prefaces should consider; if they are not very careful, this may indeed befall. When three books on the same subject arrive together, one takes up the challenge expecting that any two shall provide ammunition for dealing with the third, or that at least they can be set cyclically against one another the Midshipman Easy way. It turns out, though, that the books are so different in contents and treatment that comparison would be a fruitless exercise.

Of Dr. Dennis Shaw's book it is said that "although it is too advanced for use in schools, it will be of interest to sixth-form masters teaching physics up to scholarship level". But in this context, where it does touch on work that might be taught in class, it is neither detailed enough nor thorough enough; and outside the syllabus, those who are interested in electronics will frequently want assistance in quite advanced terms-much more about the oscilloscope, for example, than is given here. But this is professedly an introduction, and should be useful in that respect at its own level. The earlier chapters are basic circuitry with the associated mathematics, and electronics proper begins in Chapter 9 with the discussion of electrons in solids. This may well be the most profitable start for those whose later concern is primarily with transistor circuits, but the explanation is very condensed and I have doubts about the efficacy of this approach. Later there is a chapter on semi-conductor diodes and another on transistors. The thermionic diode and triode receive adequate conventional treatment, though no mention is made of the gas-filled diode or the thyratron; and there is nothing about the pentode or the photo-cell. The book ends with accounts of the motion of electrons in electric and magnetic fields, and of the cathode-ray tube. Units are adroitly handled-electrostatic deflexion in E.S.U., and magnetic deflexion in E.M.U. But the case that does need thinking about, with both together, is not mentioned; and that is the sort of thing that must be done most carefully at school. Good selections of up-to-date references and of examples to be worked through are given; and the student who follows up the text through these would find it a very helpful introduction.

Electronics for Scientists is really a combined experimental course and laboratory guide. It is largely based on apparatus units made by the Heath Co. (known in Great Britain as 'Heathkit') and designed by Profs. Malmstadt and Enke. It covers basic measurements and power supplies, amplifiers, oscillators, bridge measurements servo systems, operational amplifiers for measurement and control, and switching and timing and digital counting systems. Since valve voltmeters and Dekatron scalers and d.-c. amplifiers are finding their way into schools nowadays, this would be a useful book to many teachers, and worth the rather high price-which would repay itself in the better understanding with which expensive apparatus could be used. In an electronics laboratory equipped with the apparatus for which it was written, it would be a most useful hand-book.

Physical Electronics, by Profs. Hemenway and Henry and Dr. Caulton, plans to give what the authors call "understanding in depth". After several introductory chapters on wave-mechanics and statistics and basic physics, they select a limited number of topies and discuss them very thoroughly. Among these are the magnetron, ionic mobility and diffusion, discharge processes in gases, the klystron, and modern travelling-wave and parametric amplifiers. Plasmas and the liquid state are bracketed together for a comparative discussion. It is a fitting commentary on the speed with which things are moving nowadays that a book published in 1962 speaks of a "possible" ruby maser-which is all it could have been at the time of writing. The book gives an excellent presentation of the physics underlying the devices and processes that it covers.

G. R. NOAKES

\section{COLLEGE PHYSICS REVISED}

\section{Modern College Physics}

By Prof. Harvey E. White. Fourth edition. Pp. ix +755 . (Princeton, N.J.: D. Van Nostrand Company, Inc.; London: D. Van Nostrand Company, Ltd., 1962.) $76 s$.

HE preparation of a new edition of an elementary physics text presents several problems to the author. New knowledge must be included; some of the old must be sifted carefully, and presented in relation to the new with the help of modern resources; and whether the book is for the intending future scientist or for the student taking science as part of his liberal education the treatment should, so far as is consistent with the level, be philosophically and logically sound. Prof. White deals handsomely with the first; the second also has been considered-the Physical Science Study Committee's frictionless puck, for example, for dynamics experiments, and the use of the pulse electrometer for measuring small currents ; but he has not entirely come to grips with the third.

In singling out two points for criticism under this last heading, I am not niggling at a very good book. They are quite important, and themselves inconsistent with the excellent logical approach that the author shows in dealing with Newtonian mechanics, which is so often a weakness. The first is Ohm's Law. The concept of resistance and the ohm are introduced a whole page before Ohm's Law is mentioned; the experiment to illus. trate this is performed with a metal filament lamp, for which $V / I$ is unfortunately far from constant, and later resistance is defined as "the opposition offered to the flow of current through a circuit". This treatment misrepresents the nature of a physical law, of Ohm's Law, and of resistance.

Next, is it legitimate to defer to a later chapter the determination of $e$, to define the coulomb as a number of electrons, and the ampere as one coulomb per second ? Most of us have to start in more or less this way, deferring also much more which has to come in eventually. But if, as the author does, you import nothing else but the volt, by the time you reach the Millikan experiment this determines only the number you first thought of. One could be sympathetic if the difficulties and omissions were indicated, for there always has to be some com. promise with rigour at the start. But there is nothing anywhere in the book about the basic current-current experiments (on which the treatment of the Physical Science Study Committee wisely lays such emphasis), nor is the proper definition of the ampere mentioned. This 